\title{
In search of materiality for nonfinancial information-reporting requirements of the Directive 2014/95/EU
}

\author{
Josef Baumüller $^{1}$ iD $\cdot$ Michaela-Maria Schaffhauser-Linzatti ${ }^{2}$
}

Published online: 13 August 2018

(c) The Author(s) 2018

\begin{abstract}
Materiality of disclosures is one of the fundamental principles of the nonfinancial reporting regime introduced by the Directive 2014/95/EU ("NFI Directive"). However, despite its close link to the principle of materiality for financial reporting, specific issues arise in the context of these new reporting requirements-leading to a conception that is different also from existing definitions in the field of similar reporting practices. Furthermore, there are different types of "materialities" to be found within the Directive itself. So far, this topic has not been addressed systematically in literature, leaving many questions open and causing confusion by both preparers and readers on nonfinancial reports. Consequently, this paper identifies and links the various types of materiality by analysing, contextualizing and interpreting the relevant sections of the Directive 2014/95/EU and other reporting frameworks. It is shown that despite the expectations of many, with regards to materiality, the reporting requirements of the Directive 2014/95/EU are closer to integrated reporting than it is to sustainability reporting.
\end{abstract}

\section{Wesentlichkeit(en) in der nichtfinanziellen Berichterstattung - Eine Analyse der Berichtspflichten gemäß Richtlinie 2014/95/EU}

\section{Zusammenfassung}

Der Wesentlichkeitsgrundsatz stellt innerhalb der durch die Richtlinie 2014/95/EU („NFI-Richtlinie“) eingeführten Berichtspflichten einen zentralen Grundsatz dar. Obschon er in diesem Kontext eine enge Verknüpfung zum Verständnis von Wesentlichkeit im Rahmen der Finanzberichterstattung aufweist, stellen sich doch auch spezifische Herausforderungen des neuen Kontextes - was zu einem erforderlichen Begriffsverständnis führt, das sich von den bisher vorzufindenden vertretenen Auslegungen von Wesentlichkeit unterscheidet. Darüber hinaus zeigt sich Wesentlichkeit sogar innerhalb der neu eingeführten Berichtspflichten in mitunter unterschiedlichen Ausprägungen. Die Vielzahl an damit verbundenen (Auslegungs-)Fragen wurde jedoch von der Literatur noch nicht aufgegriffen, wodurch offene Fragen und v.a. Verunsicherung aufseiten der Berichtersteller und -adressaten verbleiben. Folglich zielt dieser Aufsatz darauf, die verschiedenen Ausprägungen von Wesentlichkeit im Kontext der Richtlinie 2014/95/EU wie auch in Abgrenzung zu anderen Berichtsvorgaben zu identifizieren und zu verbinden. Das Ergebnis zeigt zur Überraschung vieler, dass die Vorgaben dieser Richtlinie von einer stärkeren Anlehnung an das Konzept des Integrated Reporting denn an eine traditionell verstandene Nachhaltigkeitsberichterstattung geprägt sind.

Josef Baumüller

josef.baumueller@univie.ac.at

Michaela-Maria Schaffhauser-Linzatti michaela.linzatti@univie.ac.at

1 Controller Institute, University of Vienna, Vorgartenstraße 204/6, 1020 Vienna, Austria

2 University of Vienna, Oskar-Morgenstern-Platz 1, 1090 Vienna, Austria

\section{Introduction and problem statement}

The concept of materiality is of fundamental importance for accounting purposes-or "one of the cornerstones of accountancy" (Frishkoff 1970, p. 116). It serves both as a guiding principle for identifying information that is of relevance for the users of financial or other reports (i.e. minimum of required information) as well as a limitation to the amount and detail of information presented (i.e. maximum of permitted information). Nevertheless, it is also consid- 
ered one of the most pervasive concepts. In financial reporting, especially the latter aspect has received much attention over the recent years, giving the principle of materiality increased relevance on an EU level (stronger accentuation of the cost-benefit-relationship of information required by the Directive 2013/34/EU) and on an international levels (Principles of Disclosure project by the IASB to address the socalled disclosure problem: not enough relevant information as well as too much irrelevant information in financial reports; IASB 2017a).

Besides this issue's relevance for financial reporting purposes, also nonfinancial reports ${ }^{1}$ heavily rely on judgements about materiality. Due to the vastness and heterogeneity of information available and possibly of relevance for the users of such nonfinancial reports, it might even play a more important role than in financial reporting. A study conducted by the EU Commission prior to the work on its Directive 2014/95/EU pointed out that many potential users of previously published sustainability reports criticise the obvious lack of material information in them whilst contents often seem to be selective, mainly stressing positive aspects of the reporting company's performance (Wensen et al. 2011). These findings underline the relevance of two major concerns with regards to nonfinancial reporting: information overload and greenwashing (Velte 2017a). As in the context of financial reporting, the problem of information overload is considered an obstacle for deriving decision relevant information out of the reports issued (Casey Jr. 1980; Stocks and Harrell 1995; Eppler and Mengis 2004). The multidimensionality of nonfinancial information adds to that problem in its specific context, i.e. also the usefulness of such reports might be questioned because of the information overload problem. Furthermore: given the need to reconcile financial with nonfinancial information, the increase in total information available might even have an adverse effect and hamper the intended positive effects of reporting, both financial and nonfinancial, from its users' perspective as a whole (Neumann et al. 2012). The obvious view of companies on sustainability reporting practices as PR tools, a practice called greenwashing and illustrated by a vast stream of empirical literature (e.g. Marquis et al. 2016), also leads to the conclusion that newly posed nonfinancial reporting requirements might very likely lead to an aggravation of the information overload problem. The corresponding call for more focus on materiality in this context is thus considered an important as well as probably the most effective remedy against this threat (Eccles and

\footnotetext{
${ }^{1}$ In the most basic meanings of the word, nonfinancial reports are a negation of financial reports. Thus, nonfinancial reports focus on data other than financial figures. In general, the relevant contents are of a qualitative nature and also referred to as "ESG factors". For further discussion on the term "nonfinancial" in a reporting context see AK EUR (2015); Haller et al. (2017).
}

Krzus 2014, p. 133; see also the definition of "materiality"2 by Hummel and Festl-Pell 2015, p. 372).

However, the relative importance of nonfinancial information might vary more drastically between individual firms or between industries (Eccles and Serafeim 2013) as well as different reporting standards including their assessment logics employed (Edgley et al. 2015). Thus, existing literature already pointed out that considerable attention has to be paid on this determination of materiality in such relevant fields of nonfinancial reporting as sustainability reporting, integrated reporting or the provision of nonfinancial KPIs based on Art. 19 (1) of the Directive 2013/34/EU (Gelmini et al. 2015). Empirical research underlines the relevance of this assessment for a company's (nonfinancial) performance and (financial) value (Khan et al. 2016).

Directive 2014/95/EU which entered into force 2014 gave increased importance to the question of how to interpret and assess materiality in the context of nonfinancial information (CSR Europe and GRI 2017). Based on its provision in Art. 4, a large number of companies has to draw up so-called "nonfinancial reports"3 since the financial year starting on $1^{\text {st }}$ January 2017 or during the calendar year 2017. Given a translation into the national laws of German-speaking countries (Germany and Austria) which very closely follows the Directive's content and wording, this conclusion holds especially true in both of them. The analysis and identification of material matters is a key prerequisite for companies to meet these requirements and determine the contents of their reports (Frey and Rogl 2017).

However, so far no study on the specific nature and scope of the concept of materiality in this context has been undertaken. Relevant questions include the different roles and functions of this principle for the purposes of the newly introduced nonfinancial reporting requirements themselves as well as their differences to other reporting contexts (for an initial discussion of these topics AK EUR 2015). This is especially useful for both preparers and auditors of this information in order to make relevant decisions about the necessary contents of these reports. Consequently, this paper aims at closing this research gap by outlining the various aspects of materiality in the context of nonfinancial reporting in accordance with the Directive 2014/95/EU. Furthermore, the differences in the conceptions of materiality for financial, sustainability and integrated reporting purposes are contrasted with the requirements of this Directive. This is done by analysing, contextualizing and interpreting the relevant norms. By this, both prepares and readers of nonfi-

\footnotetext{
2 "[A] company"s selective disclosure on sustainability issues without full reporting of material sustainability issues to overstate its true sustainability performance.”.

${ }^{3}$ In the following chapters of this paper and for the sake of terminological distinction, nonfinancial report thus refers to the reporting provisions set forth by the Directive 2014/95/EU, unless otherwise stated.
} 
nancial reports should be provided with an improved understanding on the relevant aspects of materiality in the context of nonfinancial reporting; this in turn seems vital to ensure the effectiveness of the new reporting requirements given the considerations, aims and possible pitfalls discussed in the previous paragraphs.

\section{Conceptions of materiality}

\subsection{Materiality in financial reporting}

In accounting, the term materiality first appeared in the context of financial reporting and auditing at the turn of the $20^{\text {th }}$ century. Its purpose was arguably to make judgements about the information necessary to be presented to the users of financial statements (Edgley 2013). Eversince, it has experienced a steady increase in scope of understanding and importance for practice.

Within the European Union, the most important accounting framework is constituted by the so-called Accounting Directive, i.e. Directive 2013/34/EU. Its general provisions in Art. 4 (3) require companies to "give a true and fair view of the undertaking's assets, liabilities, financial position and profit or loss" in their annual financial statements. This is basically achieved by adhering to the accounting provisions of this Directive. These, in turn, often refer to the term of "materiality" for determining the scope of information necessary to fulfil the general provision stated before; Art. 2 (16) of this Directive sets forth the definition of materiality as used for financial reporting purposes within the EU: "'material' means the status of information where its omission or misstatement could reasonably be expected to influence decisions that users make on the basis of the financial statements of the undertaking. The materiality of individual items shall be assessed in the context of other similar items." This stresses a clear focus on quantitative aspects of financial reports whilst also taking into consideration qualitative factors (e.g. Leffson 1986). However, concrete specification of who is deemed to be the relevant users is not given by the Directive, thus leaving room for interpretation. One way of addressing this is by referring to the more extensive guidelines of the IFRS on the topic of materiality.

Similar to this definition, QC11 of the IFRS' Conceptual Framework for Financial Reporting lists "materiality" as one of the fundamental qualitative characteristics of useful financial information: "Information is material if omitting it or misstating it could influence decisions that users make on the basis of financial information about a specific reporting entity. In other words, materiality is an entity-specific aspect of relevance based on the nature or magnitude, or both, of the items to which the information relates in the context of an individual entity's financial report." With regards to this definition, there are no major differences to the Directive 2013/34/EU's understanding of materiality. However, in its section on the objectives of general purpose financial reporting, the IFRS' Conceptual Framework explains that those users are primarily "existing and potential investors, lenders and other creditors" (OB2). Consequently, information is material if it is suitable to affect decisions such as investing in a company or lending money to it. Adding to that, IAS 1.15 sets forth the principle of fair presentation, requiring financial statements to present "fairly the financial position, financial performance and cash flows of an entity". Consequently, besides a more distinct focus on providers of financial capital as point of reference for making materiality assessments, the basic understanding of the IFRS is similar to the one contained in the Directive 2013/34/EU.

Given the higher relevance of these assessments for applying the accounting provisions contained in the individual standards, Practice Statement 2-“Making Materiality Judgements" was issued in 2017 in order to give more guidance on the process of assessing materiality and interpreting its results in different contexts. It bundles the materiality requirements in various IFRS and adds practical guidance and examples. Further topics discussed include materiality with regards to prior-period information, errors, information about covenants, and materiality judgements for interim reporting. Beyond that, it outlines that the determination of materiality is to be seen as a four-step process (IASB 2017b):

1. Identification of information that is potentially material.

2. Assessment whether the information gathered in step 1 is actually material.

3. Organization of the information within the (draft) financial statements to communicate the information clearly and concisely to primary users.

4. Review of the draft financial statements to determine whether all material information is included and materiality appropriately considered on the basis of the complete set of financial statements.

As a concluding perspective, also relevant standards on auditing add further to the relevance of materiality in the context of financial reporting. ${ }^{4}$ The International Standards on Auditing (ISA) address this issue multiple times: most notably in ISA 320 ("Materiality in planning and performing an audit") and ISA 450 ("Materiality in planning and performing an audit"). Underlying these standards, ISA200 ("Overall objectives of the independent audit and the conduct of an audit in accordance with International Standards on Auditing") sets forth in its paragraph 6: "In general,

\footnotetext{
${ }^{4}$ For a detailed discussion of the links between materiality in financial reporting and auditing see Draxler and Kuntner (2010).
} 


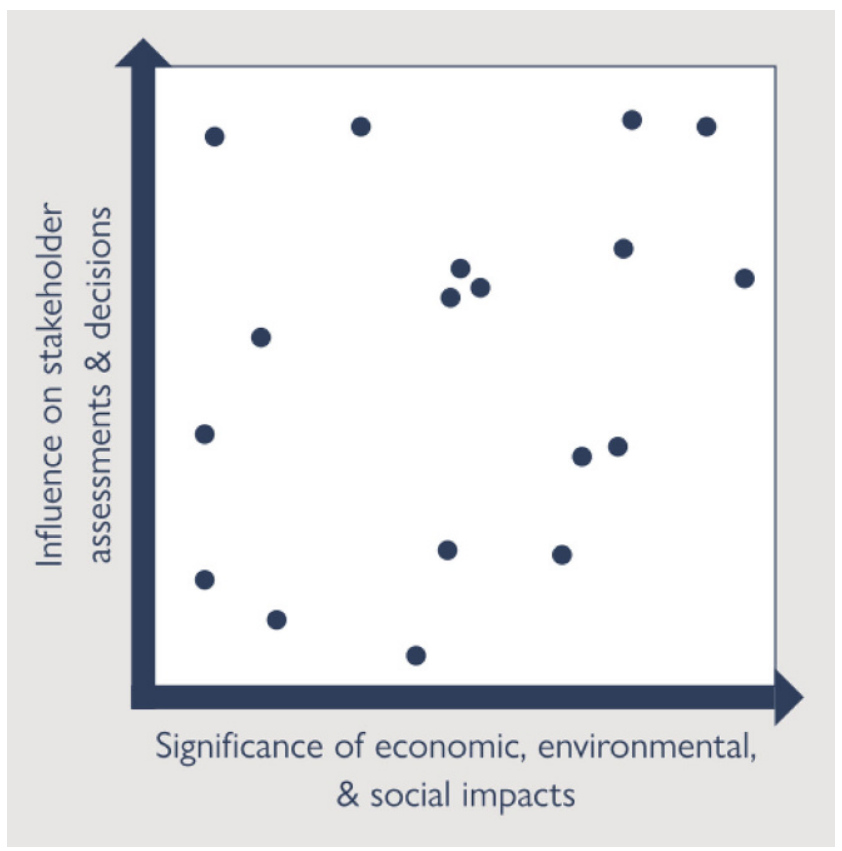

Fig. 1 Visual presentation of priorization of topics (GRI 101: Foundation 2016, p. 11)

misstatements, including omissions, are considered to be material if, individually or in the aggregate, they could be reasonably be expected to influence the economic decisions of users taken on the basis of the financial statements. Judgements about materiality are made in the light of surrounding circumstances, and are affected by the auditor's perception of the financial information needs of users of the financial statements, and by the size or nature of a misstatement, or a combination of both." ISA 320 expands on that with regards to the auditor's duties for planning and performing the audit. Even though possible benchmarks for quantitative and qualitative assessments are listed, neither of the standards does include a more concrete definition of materiality itself. ${ }^{5}$ So still, materiality as defined by the applicable reporting framework is the key point of reference for the auditor's judgements for his responsibilities (ICAEW 2017). This conclusion also applies for ISA 450 which deals with the application of materiality for assessing the effect of identified misstatements on the audit as well as the effect of uncorrected misstatements on the financial statements. Together with many illustrative examples that are given in its application guidelines, it further stresses the relevance of quantitative, but in case also qualitative aspects of materiality in this context. E. g. in the context of

\footnotetext{
5 E. g.: "For example, the auditor may consider five percent of profit before tax from continuing operations to be appropriate for a profitoriented entity in a manufacturing industry, while the auditor may consider one percent of total revenue or total expenses to be appropriate for a not-for-profit entity.".
}

classification misstatements, the auditor is required to assess effects on covenants, on individual line items or subtotals, or on key ratios (ISA 450.A20). Also, the auditing standard refers to the audited entity's financial results as a typical reference point for assessing the impact of any misstatement (ISA 450.A14).

\subsection{Materiality in sustainability reporting according to GRI standards}

Similar to the IFRS' relevance for financial reporting within the EU, the standards issued by the Global Reporting Initiative (GRI) share their importance on the field of sustainability reporting. In this context, GRI 101: Foundation 2016 (Clause 1.3) refers to the following understanding of materiality: "Relevant topics, which potentially merit inclusion in the report, are those that can reasonably be considered important for reflecting the organization's economic, environmental, and social impacts, or influencing the decisions of stakeholders." So, the distinction is made between two dimensions which both can induce materiality independently: "impacts" and "stakeholders".

"Impact" is one of the most elusive terms in sustainability accounting, given a wide range of definitions and logics for determining them. GRI's Glossary describes it as referring to "the effect an organization has on the economy, the environment, and/or society, which in turn can indicate its contribution (positive or negative) to sustainable development" (GRI Standards Glossary 2016, p. 9). Sustainable development in turn means "development that meets the needs of the present without compromising the ability of future generations to meet their own needs.

- Note 1: Sustainable development encompasses three dimensions: economic, environmental and social.

- Note 2: Sustainable development refers to broader environmental and societal interests, rather than to the interests of specific organizations." (GRI Standards Glossary 2016, p. 17).

In conclusion, impact is a very abstract conception linked to the core idea of the triple bottom line of sustainability accounting (Elkington 1997); it might (but not necessarily has to) refer to impacts on the financial situation of the reporting company as well as on impacts on various internal or external stakeholder groups.

"Stakeholders" are also understood in a very broad sense: "entity or individual that can reasonably be expected to be significantly affected by the reporting organization's activities, products and services, or whose actions can reasonably be expected to affect the ability of the organization to successfully implement its strategies and achieve its objectives" (GRI Standards Glossary 2016, p. 16). Again, it is not necessary that such stakeholder groups directly affect 
Table 1 Differences between different conceptions of materiality

\begin{tabular}{llll}
\hline & Financial Reporting & Sustainability Reporting & Integrated Reporting \\
\hline Objective & $\begin{array}{l}\text { True and fair view of financial } \\
\text { position, financial performance } \\
\text { and cash flows }\end{array}$ & Impact & Value creation \\
$\begin{array}{llll}\text { (Main) Target group of informa- } \\
\text { tion }\end{array}$ & $\begin{array}{l}\text { Providers of financial resources } \\
\text { (esp. investors) }\end{array}$ & Stakeholders (in a broad sense) & Providers of financial resources \\
$\begin{array}{l}\text { Criteria for materiality judge- } \\
\text { ments }\end{array}$ & $\begin{array}{l}\text { Mainly quantitative (but also } \\
\text { considering qualitative aspects) }\end{array}$ & $\begin{array}{l}\text { Mainly qualitative (possibly also } \\
\text { quantitative) }\end{array}$ & $\begin{array}{l}\text { Quantitative and qualitative } \\
\text { (integrated) }\end{array}$ \\
$\begin{array}{l}\text { Time considerations } \\
\text { Direction for analysis }\end{array}$ & $\begin{array}{l}\text { Primarily short term } \\
\text { Outside-in }\end{array}$ & Inside-out & Short, medium and long term \\
\hline
\end{tabular}

the reporting company's financial situation (as for financial reporting), so the GRI'S definition is very broad. Making concrete decisions about whom to include in the materiality analysis is part of the first principle for defining the reporting content in GRI 101: Foundation 2016. However: The obvious separation between impact and stakeholder decisions as set forth by the GRI Standards Glossary is in fact a point of criticism as determining the severity of an organization's activities needs to refer to a certain reference point which should be the stakeholders that are impacted by these activities to ensure a sound methodology (Baumüller 2018c).

Combining those two dimensions results in the so-called materiality matrix. This tool aims at identifying topics that are required to be included in a sustainability report. It is based on a list of topics that are potentially relevant, identified e.g. by means of interviews or by checklist-based approaches (Gaggl 2018). The focus lies on the intersection of both dimensions in the graph, however a topic can also be material based only on one of the two dimensions (GRI 101: Foundation 2016, p. 10). This leaves a lot of room for the reporting companies to make their decisions about materiality; nevertheless, the necessary judgements are mainly defined by a qualitative dimension that is characteristic for this context (Haller and Ernstberger 2006; Günther and Muschallik 2017; Fig. 1).

Finally, the GRI standards also stress the need for further judgement in the process of materiality determination. First, even the presentation of the identified material topics has to be considered carefully: "Not all material topics are of equal importance, and the emphasis within a report is expected to reflect their relative priority" (GRI 101: Foundation 2016; p. 10). As a result, material topics have to be priorized. Beyond these topics, other relevant (but immaterial) topics can be included, but this should be done with less prominence.

\subsection{Materiality in integrated reporting according to the IIRC framework}

Also in the recently emerging context of integrated reporting, materiality is considered to be "one of the most important and controversial" principles (Mio 2016, p. 3). As one of the IIRC Framework's guiding principles, it is defined as follows: "An integrated report should disclose information about matters that substantively affect the organization's ability to create value over the short, medium and long term" (IIRC 2013a, p. 5). In its background paper on materiality, this is specified: "For the purposes of $<\mathrm{IR}>$, a matter is material if it is of such relevance and importance that it could substantively influence the assessments of providers of financial capital with regards to the organization's ability to create value over the short, medium and long term". Importance refers in this context to both nature and magnitude of a matter (IIRC 2013b, p. 2).

To arrive at such a judgement about materiality, several necessary steps are outlined (IIRC 2013a):

- Identify relevant matters: Such matters are characterized by their ability to have an effect on the organization's ability to create value. This requires consideration of their effect on the organization's strategy, governance, performance or prospects.

- Evaluate importance: Furthermore, also the nature of this effect has to be assessed with regards to its (potential) effect on value creation. This involves considerations with regards to the magnitude of the matter's effect and its likelihood of occurrence.

- Prioritize matters: In a next step, the relevant matters have to be prioritized based on their magnitude.

- Determine information that has to be disclosed: Finally, both internal and external perspectives have to be considered to identify the matters relevant for disclosure. This requires regular engagement with providers of financial capital and other stakeholders so that the integrated report can meet its primary purpose.

To point out again one vital aspect: the purpose of this analysis is to give providers of financial capital information 
on how the organization is able to create value over the short, medium and long term. Compared to materiality assessments in the context of sustainability reports, the focus on the relevant stakeholder groups is thus clear and on financial matters (Maniora 2013); probability and magnitude of a matter are the main points of relevance for making judgements. Consequently, the major difference to materiality assessments in the context of financial reporting lies in the reference to the more complex process of value creation of a company in contrast to merely its financial position, financial performance and cash flows (IIRC 2013a).

\subsection{Summary}

As it has been depicted, both similarities and differences of the notion of materiality in the various contexts do exist. E.g. in all cases, the determination of materiality is considered to be a complex multi-step process that requires judgements which take into consideration both qualitative and quantitative aspects, although these aspects are differently weighted. Decision usefulness is a key criterion in all frameworks, but viewed from different perspectives. Furthermore, materiality is highly specific to the individual context and thus cannot be appropriately addressed by simple checklist-based approaches. However, Table 1 outlines the existing differences that make the notion of materiality special also with regards to the various reporting purposes.

Despite the differences outlined above, it should be noted that these concepts are also in these respects not antagonistic but characterized by different focusses instead. E. g. the objective in the context of financial reporting, true and fair view of financial position, financial performance and cash flows is also an element of the notion of impact that is relevant for sustainability reporting. However, it is not the dominating objective there but only one amongst equals; in other words: a wider range of impacts and stakeholders has to be considered (GRI 101: Foundation 2016, p. 10). The same applies for the objective of value creation which is an expanded version of the true and fair view objective in financial reporting; but going one step further, integrated reporting also balances the interests of other stakeholder groups in the relevant considerations, thus adds multidimensionality.

So, the main difference lies in the direction of analysis which is required by the concepts of reporting (and thus also materiality) discussed. Financial reporting and integrated reporting are based on an outside-in approach. I.e. they reflect how certain topics effect the organization; consequently, topics are material depending on their ability to make such effects. On the other hand, sustainability reporting as shown for the GRI framework is characterized by an inside-out approach: topics are material if they reflect effects the reporting organization has on its stakeholders and the concept of sustainability as a whole (Milla and Haberl-Arkhurst 2018). Finally, this outlines the crucial role of stakeholder identification in sustainability reporting: the more relevant they are for the organizations financial position, financial performance and cash flows (e.g. customers, financial capital providers), the more in line those materiality assessments will be with the approaches of financial reporting and integrated reporting again.

\section{Materiality based on the nonfinancial reporting requirements of the Directive 2014/95/EU}

\subsection{Overview}

Neither the terms "materiality" nor "material" are used even once throughout the reporting requirements of the Directive 2014/95/EU (Frey and Rogl 2017). This comes as a surprise given the vital role of this principle in both accounting in general and nonfinancial reporting as considered in the cases of sustainability and integrated reporting. Nevertheless, despite different wordings, several provisions of the Directive show a clear reference to the principle of materiality:

- The general provision for nonfinancial reporting in Art. 19a (1) of the Directive 2013/34/EU as introduced by the Directive 2014/95/EU— the centrepiece of the new regulations and the starting point for any question related to materiality assessment;

- the reporting requirement relating to principal risks and

- the reporting requirement relating to nonfinancial KPIs, both specifying the contents of nonfinancial reports as set out by the general provision;

- finally, the provisions granting the right to omit information from nonfinancial reports in certain cases.

This is also shown clearly when consulting the Guidelines of the EU Commission issued in summer 2017 (EU Commission 2017). Despite their unclear legal status and nonbindingness, they add clarity to the reporting requirements of the Directive 2014/95/EU and employ a different and in some cases clearer wording that explicitly relates to the term "materiality". However, these Guidelines also illustrate that this concept of materiality is not consistently used throughout the requirements of the Directive 2014/95/EU and that several "types" of materiality are in use, although closely linked. 


\subsection{Materiality in the context of the general provision for nonfinancial reporting}

Art. 19a (1) as introduced by the Directive 2014/95/EU states: "Large undertakings [...] shall include in the management report a non-financial statement containing information to the extent necessary for an understanding of the undertaking's development, performance, position and impact of its activity, relating to, as a minimum, environmental, social and employee matters, respect for human rights, anticorruption and bribery matters [...]". It uses the expression "information [...] necessary for an understanding [...]", not "material for". However: With respect to this regulation, the EU Commission's Guidelines formulate the key principle for nonfinancial reporting called "disclose material information". To specify this principle, they refer to Art. 2 (16) of the Directive 2013/34/EU, thus linking materiality to the relevance information has for its users for making decisions. Referring to this basic definition also makes sense given the fact that the nonfinancial reporting requirements are treated as a separate part of the management commentary (Kumm and Woodtli 2016).

The main question in the context relates to the scope of information that is subject to this assessment, i.e. which could possibly qualify for being material. To do so, the three components of the quoted regulation in Art. 19a (1) have to be analysed. It addresses three types of Information:

1. Information necessary for an understanding of the company's development, performance and position.

2. Information necessary for an understanding of the company's impact of its activity.

3. Information relating in any case to certain matters set forth by the Directive.

Point 3 refers to certain matters that have to be addressed once the focus is set. This focus is however determined in the intersection of points 1 and 2 :

- Point 1 directly refers to the general provision for the management report (Art. 19 (1) of the Directive 2013/34/EU). Based on the prevailing definition to this provision, companies are required to report information that is of relevance for their assets, liabilities, financial position and profit or loss. Thus, point 1 links the reporting requirements of Art. 19a (1) to a strong financial perspective.

- Point 2 introduces the new term "impact" to the accounting regime of the Directive 2013/34/EU. As discussed, it is characteristic of the context of sustainability reporting, referring to the perspective of a company's stakeholders (as discussed in Sect. 2.2.) not necessarily tied to the reporting company's financial perspective. By being added to the focus set forth by point 1 , this represents the major extension to the previous reporting requirements (Baumüller 2018b).

Those two points are linked by the word "and". This leads to the conclusion that both have to be met simultaneously-financial relevance for the company and relevance in terms of impacts. I.e. information that refers to certain impacts but is of no financial relevance is not covered by the reporting obligations in Art. 19a (1). So far, the vast majority of authors considers this to be the purpose of the nonfinancial reporting requirements (for Germany IDW 2017; for Austria Baumüller 2018a). It is also the same scope as for the reporting requirements concerning nonfinancial KPIs (Art. 19 (1) of the Directive 2013/34/EU) which were the starting point for the work on the Directive 2014/95/EU (Kumm and Woodtli 2016). And it becomes easier to handle for accounting and auditing purposes, as the linking of elusive impacts to more concrete financial aspects makes it easier to apply common approaches to the new context (Haaker and Freiberg 2017).

In other words: According to the regulations in Art. 19a (1), for nonfinancial reporting purposes only such information is deemed to be material that aligns the financial perspective on the company with its impact from the stakeholders' perspective. Still, it is providers of financial capital that receive special and decisive attention thus because of this link-similar to the idea of materiality in the context of integrated reporting, but much narrower than the conception of materiality in the context of sustainability reporting (Baumüller 2018a). However, drawing on the ideas described in the context of the latter for making the relevant assessments (as proposed by literature, e.g. Milla and Haberl-Arkhurst 2018), a materiality matrix in the context of Art. 19a (1) should show the following structure:

With regards to the other fields depicted in Fig. 2 besides the one in the upper right corner, the question of whether they might be included in a company's considerations when drawing up nonfinancial reports has to be answered in accordance with the key principles for such reports as set forth by the Guidelines of the EU Commission (EU Commission 2017). Thus, the following reasonings apply (also Baumüller 2018a):

- Including information that is necessary for the understanding of the company's impact of its activity, but not for an understanding of the company's development, performance and position in nonfinancial reporting (upper left corner of Fig. 2) extends the reporting scope to the conception of materiality as it is employed for sustainability reporting as discussed for the GRI standards. Already the option to refer to this framework for re- 


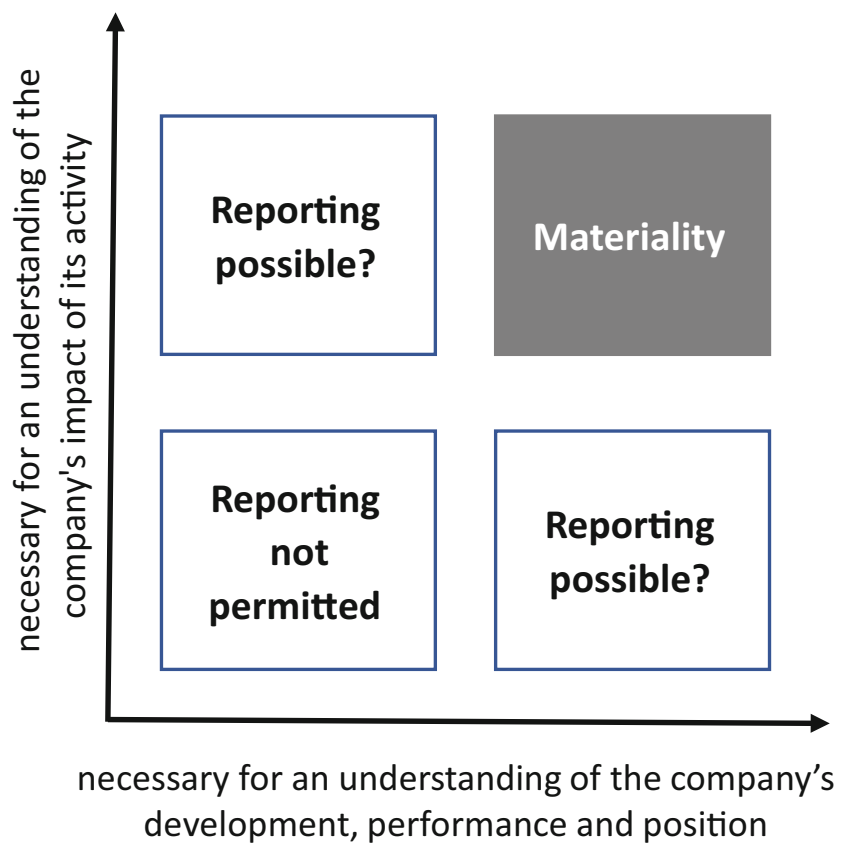

Fig. 2 Visual presentation of priorization of matters according to the Directive 2014/95/EU

porting purposes makes this—if not required—still seem a possible option.

- Consequently, also the option vice versa (lower right corner of Fig. 2) seems open to companies when preparing their reports. In this case, however, the reporting content will be in line with the focus set forth by the Directive 2013/34/EU for the management commentary (Art. 19). So, the matters covered in this case should already be part of the management commentary and would mean doubling this information in the nonfinancial report. Consequently, making references to the relevant other parts of mandatory reporting in order to keep reporting concise (another key principle of the EU Commission's Guidelines) seems the preferable option.

- Finally, concerning information that is neither necessary for the understanding of the company's impact of its activity nor for an understanding of the company's development, performance and position (lower left corner of Fig. 2), their inclusion would imply an obvious conflict with several of the key principles of the Guidelines of the EU Commission. So, in this case reporting on these matters has to be considered prohibited.

As a result, it is clearly shown that the concept of materiality is of fundamental importance for determining the content of nonfinancial reports. By building on the notion of impact caused by the organization and addressing a broad range of stakeholders, it obviously shares many similarities with sustainability reporting. This is also illustrated by vast parts of recent literature that confuse the terms nonfinan- cial reporting and sustainability reporting (for a discussion Baumüller 2018a). However, the core characteristic of nonfinancial reporting is to be found in its linking of information requirements to the organizations financial position, financial performance and cash flows. This narrows the focus of reporting obligations substantially. Amongst all the concepts discussed in Sect. 2., this shows the closest links to the idea of integrated reporting.

\subsection{Materiality in the context of reporting on nonfinancial risks}

Art. 19a (1) (d) requires reporting on "the principal risks related to those matters linked to the undertaking's operations". According to recital 8 of the Directive 2014/95/EU, this reporting requirement is one of the most fundamental of the entire nonfinancial reporting regime.

The term "principal risk" is explained in more detail in recital 8. It requires companies to make their judgements on materiality based on two aspects: likeliness of occurrence and severity of impact. It is not further explained which threshold is to be applied for assessing the likeliness of a certain risk to materialize; due to this, it seems to be appropriate to interpret it as "more likely than not", i.e. $>50 \%$, unless the severity of impact for a certain risk is especially high. This severity is further explained in recital 8: "The severity of such impacts should be judged by their scale and gravity." This might be illustrated e.g. by the number of people affected and the way they are affected. Also, it shows a high degree of moral considerations that might be necessary for many of these assessments. The required focus is different from the focus of traditional risk management practices, as these typically focus only on the risks for the company itself (Richter et al. 2017). In contrast to the general provision, a financial perspective is irrelevant for this context, thus.

As a result, Art. 19a (1) (d) indicates the need for employing a separate materiality matrix in order to arrive at its judgement about materiality. This kind of materiality, however, does not intended to identify relevant information for accounting purposes, but just material nonfinancial risks instead. Whether or not these risks have to be included in the nonfinancial reports depends on a second judgement about materiality - this time in the sense of the general provision as illustrated above. Nevertheless, it is most likely that material risks are also material for the users of nonfinancial reports, have an effect on the financial position, financial performance and cash flows, and thus have to be reported (Baumüller 2018a). Furthermore, the existence of material risks might indicate the materiality of a certain matter to be reported-whilst a matter identified as material will most often be associated with one or several material risks. Still, from a processual perspective this separation of the two con- 
ceptions of materiality employed in this case is necessary. It does not matter which of the two materiality analyses is conducted first. To ensure the completeness of information generated it might seem favourable to perform both analyses independently and to match their results in a second step.

\subsection{Materiality in the context of nonfinancial KPIs}

Art. 19a (1) (e) requires the presentation of "non-financial key performance indicators relevant to the particular business" in the nonfinancial report. The EU Commission's Guidelines further stress the importance of the materiality principle already inherent to the word "key" (Baumüller 2016): "Companies are encouraged to disclose material KPIs, both general and sectoral" (EU Commission 2017, p. 13).

The requirement set forth in Art. 19a (1) (e) systematically refers to the matters listed in the general provision of Art. 19a. I. e. firstly, the material matters are to be identified. Secondly, the material nonfinancial KPIs for each one of these matters have to be identified. For each matter the relevance of KPIs can vary-especially when considering the further reporting requirements concerning policies, due diligence processes and outcomes according to Art. 19a (1) (b) and (c). E.g. whilst anti-corruption and bribery matters might require more detailed explanation of due diligence processes and nonfinancial KPIs might be difficult to find, environmental or social matters might require more extensive reporting of nonfinancial KPIs. However, the wording of Art. 19a (1) (e) also suggests that every matter is to be supported by one KPI at least.

So whilst the interpretation is the same as in the general provision, the scope of its application is different. In literature, also using a checklist approach indicating possible nonfinancial KPIs for each material matter and subsequently judging the materiality of those possible KPIs - similar to the approach described for identifying (possible) material matters in Sect. 3.2-is proposed as viable to meet this reporting requirement. Guidelines such as the GRI standards or the EU Commission's Guidelines will often serve as points of reference (Baumüller 2018c; Frey et al. 2018).

At the same time, the principle of materiality also limits the number of KPIs given to a reasonable amount. Including to many KPIs without relevance for the users of nonfinancial reports would otherwise conflict with the principles of clearness and conciseness.

\subsection{Materiality and the right to omit information}

One of the last provisions in Art. 19a (1) states: "Member States may allow information relating to impending devel- opments or matters in the course of negotiation to be omitted [...] provided that such omission does not prevent a fair and balanced understanding of the undertaking's development, performance, position and impact of its activity." It is amongst the most controversially discussed regulations of the Directive 2014/95/EU, as it partially repeats the wording of the general provision, adding to this the requirement that any omitted information must not be material in the sense that it is detrimental to meeting the general provision's aim (Baumüller 2018a).

If the same conception of materiality would apply in both cases, then there would be no possibility to exercise this option: A reporting obligation only arises in the case a matter is material, and in consequence it could not be immaterial at the same time. However, literature on the interpretation of similar provisions in the field of financial reporting - such as $\S 242$ (2) of the Austrian Enterprise Code or $\$ 286$ (3) German Commercial Code-offer a solution (Baumüller and Grbenic 2015): Materiality in the context of this regulation refers to overall materiality of all information provided within the nonfinancial report (Baumüller 2018a). I.e. even if all the information given within the report is material with regards to itself, if taken together some of it might be omitted granted that

- the further requirements for this omission set forth in Art. 19a (1) are met and

- by omitting this information, the users of the nonfinancial report are not led to other conclusions by the remaining information than in the case this omitted information would be given.

In consequence, this gives special relevance to the last sentence of the definition of materiality in Art. 2 (16) of the Directive 2014/34/EU: "The materiality of individual items shall be assessed in the context of other similar items." If a company wants to make use of this right granted, it will be necessary to provide sufficient documentation on its considerations concerning the interrelationship of all the information provided and the judgements they are expected to induce with regards to their users.

\section{Conclusion and implications}

The concept of materiality plays in the field of nonfinancial reporting a role at least as important as for financial reporting. However, the questions associated with it and the scope and impact of judgements required go far beyond it. This makes it one of those aspects of the new reporting regime which require closest attention by preparers, auditors, and users (Stawinoga 2017).

The requirements of the Directive 2014/95/EU establish a regime for assessing materiality that builds on materi- 
ality for financial reporting purposes but introduces new elements which have to be considered. It becomes easier to handle for preparers and auditors, but also more pragmatic compared to practices in sustainability reporting in that respect; a nonfinancial report's link to the financial position, financial performance and cash flows of the company distinguishes it further. In fact, nonfinancial reporting as established by the Directive 2014/95/EU shows many similarities to the concept of integrated reporting as set forth by the IIRC. This is in line with the perspective for the current regulation on nonfinancial reporting within the EU to develop into this direction over the next revisions of the Directive 2014/95/EU (Velte 2017b).

This conclusion might come to the disillusionment of many who consider the Directive as promotor towards more sustainable corporate practices from a mere moral standpoint. In contrast, the paper shows that it is another old idea of sustainability management that gains momentum and is the driving factor behind the new reporting regime: the idea of the "business case for sustainability" (Salzmann et al. 2005). If this business case is identified and communicated properly via the means of nonfinancial reports, relying on the application of the principle of materiality, then it might serve the aims of sustainability more, however, than (in financial terms) less down-to-earth approaches of sustainability reporting in the past.

Funding Open access funding provided by University of Vienna.

Conflict of interest J. Baumüller and M.-M. Schaffhauser-Linzatti declare that they have no competing interests.

Open Access This article is distributed under the terms of the Creative Commons Attribution 4.0 International License (http:// creativecommons.org/licenses/by/4.0/), which permits unrestricted use, distribution, and reproduction in any medium, provided you give appropriate credit to the original author(s) and the source, provide a link to the Creative Commons license, and indicate if changes were made.

\section{References}

AK EUR (2015) Nichtfinanzielle Leistungsindikatoren - Bedeutung für die Finanzberichterstattung. Schmalenbachs $\mathrm{Z}$ betriebswirtsch Forsch 67(2):235-258

Baumüller (2016) Key Performance Indicators (KPI). Steuer Wirtschaftskartei 91(25):1111-1113

Baumüller (2018a) § 243b UGB: Nichtfinanzielle Erklärung, nichtfinanzieller Bericht. In: Bertl, Mandl (eds) Handbuch zum RLG. LexisNexis, Vienna, pp I-62

Baumüller (2018b) Zum Wahlrecht zur Zusammenfassung von Lageund Konzernlagebericht im Kontext der nichtfinanziellen Berichterstattung. Prax Int Rechnungsleg 14(2):35-40

Baumüller (2018c) Wesentlichkeit(en) im Rahmen der nichtfinanziellen Berichterstattung. IWP J 20(1):18-25

Baumüller, Grbenic (2015) § 241 UGB: Unterlassen von Angaben. In: Zib, Dellinger (eds) Großkommentar UGB, vol. III, part 2. LexisNexis, Vienna, pp 220-246

Casey Jr. (1980) Variation in accounting information load: the effect on loan officers' predictions of bankruptcy. Account Rev 55(1):36-49
Commission EU (2017) Guidelines on non-financial reporting (methodology for reporting non-financial information) (2017/C 215/01)

CSR Europe, GRI (2017) Member State Implementation of Directive 2014/95/EU. https://www.accountancyeurope.eu/wp-content/ uploads/NFR-Publication-3-May-revision.pdf. Accessed: 6 Aug 2018

Draxler, Kuntner (2010) ISA 320 oder die Wesentlichkeit im Rahmen der Prüfung von Jahresabschlüssen. Z Recht Rechnungswesen 20(9):283-290

Eccles, Krzus (2014) The integrated reporting movement: meaning, momentum, motives, and materiality. Wiley, Hoboken

Eccles, Serafeim (2013) The performance frontier: innovating for a sustainable strategy. Harv Bus Rev 91(5):50-60

Edgley (2013) A genealogy of accounting materiality. Crit Perspect Account 25(3):255-271

Edgley, Atkins (2015) The adoption of the materiality concept in social and environmental reporting assurance: a field study approach. $\mathrm{Br}$ Account Rev 47(1):1-18

Elkington (1997) Cannibals with forks: the triple bottom line of 21st century business. Wiley, Hoboken

Eppler, Mengis (2004) The concept of information overload: a review of literature from organization science, accounting, marketing, MIS, and related disciplines. Inf Soc 20(5):325-344

Frey, Rogl (2017) Inhaltliche Anforderungen an die Nachhaltigkeitsberichterstattung. CFO 11(3):98-101

Frey, Haberl-Arkhurst, Baumüller (2018) NaDiVeG: Gesetzliche Anforderungen an die nichtfinanzielle Berichterstattung - Herausforderungen für den Berufsstand. In: IWP (ed) WirtschaftsprüferJahrbuch 2018. Linde, Vienna, pp 79-106

Frishkoff (1970) An empirical investigation of the concept of materiality in accounting. J Account Res 8:116-129. Empirical research in accounting: selected studies 1970

Gaggl (2018) Nachhaltigkeits-Controlling. In: Eschenbach, Baumüller, Siller (eds) Controlling. LexisNexis, Vienna, pp 339-377

Gelmini, Bavagnoli, Comoli, Riva (2015) Waiting for materiality in the context of integrated reporting. In: Songini, Pistoni (eds) Sustainability disclosure: state of the art and new directions. Emerald Group, Bingley, pp 135-162

Günther, Muschallik (2017) Identifikation wesentlicher Themen im Rahmen der Nachhaltigkeitsberichterstattung. Z Int Katpitalmarktorient Rechnungsleg 17(10):421-425

Haaker, Freiberg (2017) Kodifizierung und Definition von Wesentlichkeit. Prax Int Rechnungsleg 13(11):351-352

Haller, Ernstberger (2006) Global Reporting Initiative - Internationale Leitlinien zur Erstellung von Nachhaltigkeitsberichten. Betriebs Berater 61(46):2516-2524

Haller, Link, Groß (2017) The term 'non-financial information'-A semantic analysis of a key feature of current and future corporate reporting. Account Eur 14(3):407-429

Hummel, Festl-Pell (2015) Much ado about nothing? Sustainability disclosure in the banking industry. J Bus Econ Ethics 16(3): 369-393

IASB (2017a) DP/2017/1 disclosure initiative-principles of disclosure. IASB, London

IASB (2017b) IFRS practice statement 2: making materiality judgements. IASB, London

ICAEW (2017) Materiality in the audit of financial statements. ICAEW, London

IDW (2017) Positionspapier zu Pflichten und Zweifelsfragen zur nichtfinanziellen Erklärung als Bestandteil der Unternehmensführung (Stand 14.6.2017). IDW, Düsseldorf

IIRC (2013a) The International 〈IR〉 Framework. http:// integratedreporting.org/wp-content/uploads/2013/12/13-1208-THE-INTERNATIONAL-IR-FRAMEWORK-2-1.pdf. Accessed: 6 Aug 2018

IIRC (2013b) Background paper: materiality. http:// integratedreporting.org/wp-content/uploads/2013/03/IRBackground-Paper-Materiality.pdf. Accessed: 6 Aug 2018

Khan, Serafeim, Yoon (2016) Corporate sustainability: first evidence on materiality. Account Rev 91(6):1697-1724 
Kumm, Woodtli (2016) Nachhaltigkeitsberichterstattung: Die Umsetzung der Ergänzungen der Bilanzrichtlinie um die Pflicht $\mathrm{zu}$ nichtfinanziellen Angaben im RefE eines CSR-Richtlinie-Umsetzungsgesetzes. Konzern 14(5):218-232

Leffson (1986) Wesentlich. In: Leffson, Rückle, Großfeld (eds) Handwörterbuch unbestimmter Rechtsbegriffe im Bilanzrecht des HGB. Dr. Otto Schmidt, Cologne, pp 434-447

Maniora (2013) Der GRI G4 Standard - Synergie oder Antagonismus zum IIRC-Rahmenwerk? Z Int Katpitalmarktorient Rechnungsleg 13(10):479-489

Marquis, Toffel, Zhou (2016) Scrutiny, norms, and selective disclosure: a global study of greenwashing. Organ Sci 27(2):483-504

Milla, Haberl-Arkhurst (2018) Wesentlichkeitsanalyse in der nichtfinanziellen Berichterstattung. Z Recht Rechnungswesen 28(1): 23-27

Mio (2016) Integrated reporting: the IIRC framework. In: Mio (ed) Integrated reporting. Palgrave Macmillan UK, London, pp 1-18

Neumann, Cauvin, Roberts (2012) Management control systems dilemma: reconciling sustainability with information overload. In: Epstein, and Lee (eds) Advances in management accounting, volume 20. Emerald Group, Bingley, pp 1-28

Richter, Johne, König (2017) Umsetzung der CSR-Richtlinie in nationales Recht. Wirtschaftsprüf 70(10):566-572
Salzmann, Ionescu-Somers, Steger (2005) The business case for corporate sustainability: literature review and research options. Eur Manag J 23(1):27-36

Stawinoga (2017) Die Richtlinie 2014/95/EU und das CSR-RichtlinieUmsetzungsgesetz - Eine normative Analyse des Transformationsprozesses sowie daraus resultierender Implikationen für die Rechnungslegungs- und Prüfungspraxis. NachhaltigkeitsManagementForum 25(3-4):213-227

Stocks, Harrell (1995) The impact of an increase in accounting information level on the judgment of quality of individuals and groups. Account Organ Soc 20(7/8):685-700

Velte (2017a) Prüfung der nichtfinanziellen Erklärung nach dem CSR-Richtlinie-Umsetzungsgesetz. Z Int Rechnungsleg 12(7-8): 325-328

Velte (2017b) Zukunft der nichtfinanziellen Berichterstattung - Das CSR-Richtlinie-Umsetzungsgesetz als Zwischenlösung!? Betrieb 70(48):2813-2820

Wensen, Broer, Klein, Knopf (2011) The state of play in sustainability reporting in the EU. ec.europa.eu/social/BlobServlet? docId=6727\&langId=en. Accessed: 6 Aug 2018 